\title{
Aeropyrum camini sp. nov., a strictly aerobic, hyperthermophilic archaeon from a deep-sea hydrothermal vent chimney
}

Correspondence

Satoshi Nakagawa

nakasato@kais.kyoto-u.ac.jp

\author{
Satoshi Nakagawa, ${ }^{1}$ Ken Takai, ${ }^{2}$ Koki Horikoshi ${ }^{2}$ and Yoshihiko Sako ${ }^{1}$ \\ 'Laboratory of Marine Microbiology, Graduate School of Agriculture, Kyoto University, \\ Kyoto 606-8502, Japan \\ ${ }^{2}$ Subground Animalcules Retrieval (SUGAR) Project, Frontier Research System for \\ Extremophiles, Japan Marine Science \& Technology Center, 2-15 Natsushima-cho, \\ Yokosuka 237-0061, Japan
}

The family Desulfurococcaceae comprises eight genera, Desulfurococcus, Aeropyrum, Ignicoccus, Staphylothermus, Stetteria, Sulfophobococcus, Thermosphaera and Thermodiscus (Huber \& Stetter, 2001). Members of the family Desulfurococcaceae, growing optimally at $85-95^{\circ} \mathrm{C}$, have been isolated from marine and terrestrial hydrothermal systems, and are strict anaerobes with fermentative metabolism or anaerobic respiration using sulfur or thiosulfate as electron acceptors, except for Aeropyrum pernix (Huber \& Stetter, 2001). A. pernix is a strictly aerobic, heterotrophic and hyperthermophilic archaeon. The type strain of the species, strain $\mathrm{K} 1^{\mathrm{T}}$, was isolated from a coastal solfataric thermal vent in Kodakara-Jima Island, south-western Japan (Sako et al., 1996a), and 11 additional strains were isolated from another coastal shallow hydrothermal vent and a coastal hot spring in south-western Japan (Nomura et al., 2002). In the phylum Crenarchaeota, A. pernix strain $\mathrm{K}^{\mathrm{T}}$ is unique in its strictly aerobic, sulfur-independent and neutrophilic growth. The complete genome sequence of this archaeon was determined for the first time in Crenarchaeota

Published online ahead of print on 1 August 2003 as DOI 10.1099/ ijs.0.02826-0.

The DDBJ/EMBL/GenBank accession number for the almost complete $16 \mathrm{~S}$ rDNA sequence (1562 bp) of strain $\mathrm{SY} 1^{\top}$ is $\mathrm{AB} 109559$.

Growth curves are available as supplementary material in IJSEM Online.
(Kawarabayasi et al., 1999), and a number of molecular biological characterizations of its hyperthermophilic enzymes have been reported (e.g. Sako et al., 1997; Yamano et al., 1999; Tachibana et al., 2000; Hansen et al., 2002; Daimon et al., 2002; Jeon \& Ishikawa, 2002). Although A. pernix strain $\mathrm{K}^{\mathrm{T}}$ has become one of the most extensively studied archaea with respect to its molecular biology, little is known about its ecological impacts, physiological diversity and distribution in natural environments.

To our knowledge, the habitats for members of the genus Aeropyrum are highly restricted to coastal geothermal fields in south-western Japan, at temperatures higher than $85^{\circ} \mathrm{C}$ and neutral to weakly alkaline pH (Sako et al., 1996a; Nomura et al., 2002). Similarly, hyperthermophilic archaea, capable of growing under an atmosphere of air such as Acidianus (Segerer et al., 1986; Zillig et al., 1986), Sulfurisphaera (Kurosawa et al., 1998), Sulfolobus (Zillig et al., 1980; Grogan et al., 1990; Jan et al., 1999; Suzuki et al., 2002) and Pyrobaculum (Sako et al., 2001; Amo et al., 2002) species isolated in terrestrial hot springs, have been never isolated from deep-sea hydrothermal environments. However, we have recently isolated strictly aerobic thermophiles, Marinithermus hydrothermalis strain $\mathrm{T}^{\mathrm{T}}$ and Rhodothermus sp. from a deep-sea hydrothermal vent chimney (Sako et al., 2003). In addition, several strictly or facultatively aerobic thermophiles have been isolated from deep-sea 
hydrothermal chimney structures (Marteinsson et al., 1995, 1999; Blöchl et al., 1997; Miroshnichenko et al., 2003a, b). In this study, we sought to cultivate aerobic hyperthermophiles from a deep-sea hydrothermal vent chimney at the Suiyo Seamount in the Izu-Bonin Arc, Japan.

\section{Sample collection, enrichment and purification}

Sample collection and subsampling procedures were described previously (Sako et al., 2003; Nakagawa et al., 2003; Takai et al., 2003a). A portion of the subsample (approx. $10 \mathrm{~g}$ ) obtained from the chimney surface $(1-3 \mathrm{~mm})$ was suspended with $20 \mathrm{ml}$ sterilized $\mathrm{MJ}$ synthetic sea water (Sako et al., 1996b) containing 0.05\% (w/v) sodium sulfide in a $100 \mathrm{ml}$ glass bottle (Schott) tightly sealed with a butyl rubber cap under a $\mathrm{N}_{2}$ atmosphere. The suspended slurry was used to inoculate a series of media including MJYPV medium (Sako et al., 2003) and the cultures were incubated at 70 and $85^{\circ} \mathrm{C}$ in a dry oven on board.

Growth of aerobic thermophiles was observed in MJYPV medium after 1 days incubation at both temperatures. Tubes inoculated by other parts of the chimney provide no positive enrichment even after 5 days incubation at both temperatures. The enrichment culture at $70{ }^{\circ} \mathrm{C}$ contained rod-shaped cells, while the culture at $85^{\circ} \mathrm{C}$ contained highly motile irregular cocci. Successive transfers of the irregular cocci grown at $85^{\circ} \mathrm{C}$ were accomplished by using JX medium (Sako et al., 1996a) at $85^{\circ} \mathrm{C}$, because those cells grew inconsistently in MJYPV medium.

To obtain a pure culture of irregular cocci grown at $85^{\circ} \mathrm{C}$, the enriched cells were streaked onto JX plates hardened with $0.5 \%(\mathrm{w} / \mathrm{v})$ Gelrite gellan gum (Sigma). The plates were incubated at $85^{\circ} \mathrm{C}$ in a tightly sealed polycarbonate jar to prevent evaporation. After 3-5 days incubation, small, spherical (1-2 $\mathrm{mm}$ in diameter) and light-yellow colonies were formed on the surface of the plates. Well-isolated colonies were picked, and the cells were incubated in fresh liquid JX medium at $85^{\circ} \mathrm{C}$. In order to ensure purity, the streaking and isolation step was repeated at least three times. The first pure culture was designated strain $\mathrm{SY}^{\mathrm{T}}$ $\left(=\right.$ JCM $12091^{\mathrm{T}}=$ ATCC BAA-758 $\left.{ }^{\mathrm{T}}\right)$ and was investigated in detail. The purity was confirmed routinely by microscopic examination and by repeated partial sequencing of the $16 \mathrm{~S}$ rDNA using several PCR primers.

\section{Morphology}

Cells were routinely observed with a differential interference microscope (UFX; Nikon). Transmission electron microscopy of negatively stained cells and thin sections of the cells was carried out as described by Zillig et al. (1990) and Sako et al. (2003). Cells grown in JX medium at $85^{\circ} \mathrm{C}$ in the mid-exponential growth phase were used for electron microscopy. The cells were Gram-negative cocci, which were about $1 \cdot 2-2 \cdot 1 \mu \mathrm{m}$ in diameter. Electron microscopy of thin sections showed that the cell envelope is composed of a cytoplasmic membrane, a periplasmic space and a thin

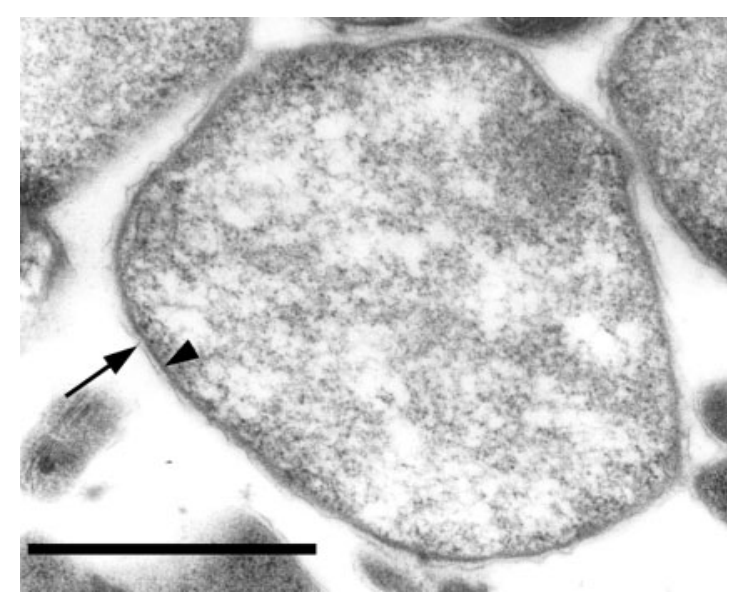

Fig. 1. Electron micrograph of a thin section of Aeropyrum camini strain $\mathrm{SY}^{\top}{ }^{\top}$ cells showing cytoplasmic membrane (arrowhead) and thin electron-dense layer (arrow), presumably representing the S-layer. Bar, $1 \mu \mathrm{m}$.

electron-dense layer, presumably representing the S-layer of protein complexes (Fig. 1). Flagella were not observed although motility was evident under the light microscopic observation. No sporulation was observed. Pili-like filaments were often observed under epifluorescence microscopic observation. These morphological properties of the new isolate were generally similar to those of $A$. pernix strain $\mathrm{K} 1^{\mathrm{T}}$ (Sako et al., 1996a).

\section{Growth characteristics}

The isolate was originally enriched in MJYPV medium (Sako et al., 2003), containing 1 g yeast extract (Difco) and tryptone (Difco), and $10 \mathrm{ml}$ vitamin solution (Balch et al., 1979) per litre of MJ synthetic sea water (Sako et al., 1996b). Then, the isolate was purified and routinely cultivated with JX medium (Sako et al., 1996a), which contained $1 \mathrm{~g}$ yeast extract (Difco) and tryptone (Difco) per litre of Jamarin S (JS) synthetic sea water (Jamarin Laboratory, Osaka, Japan). The isolate showed no growth on JXTm medium, which was suitable for the cultivation of $A$. pernix strain $\mathrm{K}^{\mathrm{T}}$ (Nomura et al., 2002). Marine broth 2216 (Difco) could be used in place of JX medium to culture the isolate.

Growth of the new isolate under various conditions was determined by direct cell counts after staining with 4',6diamidino-2-phenylindole (DAPI) (Porter \& Feig, 1980) using a Nikon Eclipse E800 microscope equipped with a colour chilled 3 CCD camera system (C5810; Hamamatsu Hokutonikusu). To determine temperature, $\mathrm{pH}$ and salinity ranges for growth, duplicate cultures were grown in cotton-plugged $300 \mathrm{ml}$ Erlenmeyer flasks containing $100 \mathrm{ml}$ medium in an air-batch rotary shaker (RGS-32.TT; Sanki Seiki) at 100 r.p.m. in all cases. At temperatures above $100{ }^{\circ} \mathrm{C}$, screw-capped test tubes were used to prevent the evaporation of the medium. The isolate grew at $70-97^{\circ} \mathrm{C}$, showing optimum growth at $85{ }^{\circ} \mathrm{C}$, and the generation time 
at $85^{\circ} \mathrm{C}$ was $220 \mathrm{~min}$. No growth was observed below $65^{\circ} \mathrm{C}$ or above $100{ }^{\circ} \mathrm{C}$ (see supplementary Fig. 1a in IJSEM Online). The effects of $\mathrm{pH}$ and salinity on the growth of the isolate were determined at $85^{\circ} \mathrm{C}$. To determine the effect of $\mathrm{pH}$ on growth, the $\mathrm{pH}$ of JX medium containing

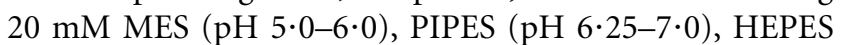

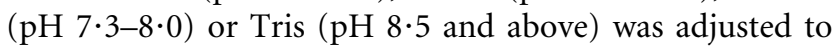
the designated values with $\mathrm{H}_{2} \mathrm{SO}_{4}$ or $\mathrm{NaOH}$ at room temperature. The $\mathrm{pH}$ value was checked after autoclaving and was aseptically readjusted with $\mathrm{H}_{2} \mathrm{SO}_{4}$ or $\mathrm{NaOH}$ at room temperature if necessary. The $\mathrm{pH}$ values of all media were stable during the cultivation period. Growth of the isolate occurred between $\mathrm{pH} 6 \cdot 5$ and $8 \cdot 8$, with optimum growth at about $\mathrm{pH} 8 \cdot 0$. No growth was detected below pH $6 \cdot 0$ or above $\mathrm{pH} 9 \cdot 2$ (supplementary Fig. $1 \mathrm{~b}$ in IJSEM online). To determine the effect of salinity on the growth of the isolate, JX medium was prepared with varying dilutions of $3 \times$ JS synthetic sea water $(1 \times$ JS synthetic sea water contains $35 \mathrm{~g}$ sea salts $\mathrm{l}^{-1}$ ). The isolate grew at $2 \cdot 2-5 \cdot 3 \%$ $(\mathrm{w} / \mathrm{v})$ salinity, with optimum growth at $3.5 \%$, which is the salinity of JX medium; no growth was observed below $1.8 \%$ or above $6.0 \%$ salinity (supplementary Fig. 1c in IJSEM Online). The effect of thiosulfate on the growth of the isolate was determined at $85^{\circ} \mathrm{C}$ with JXT medium (Sako et al., 1996a), which contains $0 \cdot 1 \%(w / v)$ sodium thiosulfate in JX medium. The maximum cell density of the isolate was increased about twofold by the addition of thiosulfate, and reached up to $1 \cdot 2 \times 10^{9}$ cells ml ${ }^{-1}$, although the generation time was not varied. Other sulfurbearing compounds such as $0 \cdot 1 \%(\mathrm{w} / \mathrm{v}) \mathrm{Na}_{2} \mathrm{SO}_{3}, \mathrm{Na}_{2} \mathrm{SO}_{4}$ or cysteine hydrochloride did not affect the growth of the isolate, however $3 \%$ of $S^{0}$ completely inhibited growth. The effect of $\mathrm{O}_{2}$ concentration in the gas phase on the growth of the isolate was determined at $85^{\circ} \mathrm{C}$ as described before (Nakagawa et al., 2003). $\mathrm{O}_{2}$ final concentrations of 0-25\% $(\mathrm{v} / \mathrm{v})$ were tested at $350 \mathrm{kPa}$. For comparison, A. pernix strain $\mathrm{K} 1^{\mathrm{T}}$ was cultured under the same conditions. Both strains were found to grow optimally with $5 \cdot 0 \% \mathrm{O}_{2}$.

In an attempt to examine whether or not the new isolate was able to grow under anaerobic conditions, $80 \% \mathrm{H}_{2}+$ $20 \% \mathrm{CO}_{2}$ or $80 \% \mathrm{~N}_{2}+20 \% \mathrm{CO}_{2}(200 \mathrm{kPa})$ were tested as a gas phase instead of air with JX medium in the presence or absence of possible alternative electron acceptors such as $0 \cdot 1 \%(\mathrm{w} / \mathrm{v}) \mathrm{NaNO}_{3}, \mathrm{Na}_{2} \mathrm{SO}_{3}, \mathrm{NaNO}_{2}$ or $\mathrm{Na}_{2} \mathrm{~S}_{2} \mathrm{O}_{3}$. In order to ensure anaerobic growth conditions, $10 \%(\mathrm{w} / \mathrm{v})$ $\mathrm{Na}_{2} \mathrm{~S}_{9} 9 \mathrm{H}_{2} \mathrm{O}$ solution ( $\mathrm{pH} 7 \cdot 5$, adjusted with $\mathrm{H}_{2} \mathrm{SO}_{4}$ and autoclaved separately) was added to the medium at a final concentration of $0.05 \%(\mathrm{w} / \mathrm{v})$. Autotrophic growth was determined with air using JS synthetic sea water containing $1 \%(\mathrm{v} / \mathrm{v})$ vitamin solution (Balch et al., 1979), supplemented with a possible electron donor $\left(0 \cdot 1 \%\right.$ of $\mathrm{Na}_{2} \mathrm{~S}_{2} \mathrm{O}_{3}$, $\mathrm{NaNO}_{2}$ or $\left.\mathrm{Na}_{2} \mathrm{SO}_{3}\right)$ and $0 \cdot 1 \%(\mathrm{w} / \mathrm{v}) \mathrm{NaHCO}_{3}$ as a carbon source. The isolate was found to be unable to grow under any of the anaerobic or autotrophic conditions tested in this study.

In an attempt to find organic substrates that could support the growth of the isolate, various organic substrates were tested instead of both yeast extract and tryptone in JX medium. Each of the following substrates was added at concentrations of 0.02 or $0.2 \%(\mathrm{w} / \mathrm{v})$ : L-arginine, L-asparagine, L-asparate, L-glutamate, L-phenylalanine, L-proline, L-serine, L-valine, Casamino acids, gelatin, D-(-)-fructose, D- $(+)$-glucose, galactose, myo-inositol, D-sorbitol, D- $(+)$-xylose, D- $(+)$-cellobiose, lactose, maltose, D- $(+)$-trehalose, sucrose, chitin, starch, sodium acetate, citrate, glycerol, L-malate, sodium pyruvate, casein, yeast extract (Difco) and tryptone (Difco). These tests were performed at temperatures of 85 and $75^{\circ} \mathrm{C}$ in shake flasks, and run in duplicate. The isolate was found to be able to utilize only complex proteinaceous substrates such as yeast extract and tryptone as energy and carbon sources, but not casein.

Sensitivity to antibiotics chloramphenicol, ampicillin, rifampicin and kanamycin at a final concentration of $100 \mu \mathrm{g} \mathrm{ml}^{-1}$ was determined in JX medium at $70^{\circ} \mathrm{C}$. These antibiotics were confirmed to be effective at $70{ }^{\circ} \mathrm{C}$ as described previously (Sako et al., 1996a). The isolate was not sensitive to ampicillin or kanamycin, but was sensitive to chloramphenicol and rifampicin. This susceptibility to antibiotics of the isolate is similar to that of A. pernix strain $\mathrm{K}^{\mathrm{T}}$ (Sako et al., 1996a).

\section{Isolation and base composition of DNA}

Genomic DNA was prepared as described by Lauerer et al. (1986). The G + C content (mol\%) of the genomic DNA was determined by direct analysis of the deoxyribonucleotides using HPLC with a DNA-GC kit (Yamasa Shouyu) after digestion of the DNA with nuclease P1 (Tamaoka \& Komagata, 1984). The $\mathrm{G}+\mathrm{C}$ content of the genomic DNA of strain $\mathrm{SY}^{\mathrm{T}}$ was found to be $54 \cdot 4 \mathrm{~mol} \%$, which was similar to that of A. pernix strain $\mathrm{K}^{\mathrm{T}}$ (Table 1 ).

\section{Phylogenetic analyses}

The 16S rRNA gene (rDNA) was amplified by PCR using Arch 21F and 1492R primers (Lane, 1985; DeLong, 1992). Although a PCR product of approximately $1.5 \mathrm{~kb}$ was expected with this primer set, a product of $1.6 \mathrm{~kb}$ was obtained from the reaction. The result indicated that the 16S rDNA of the isolate contained intron-like intervening sequences as observed in other hyperthermophilic archaea such as Pyrobaculum (Burggraf et al., 1993; Takai \& Horikoshi, 1999b), Thermoproteus (Itoh et al., 1998) and Aeropyrum (Nomura et al., 1998, 2002). The sequence of the PCR product was directly determined in both strands using the dideoxynucleotide chain-termination method with a DNA sequencer model 3100 (Perkin Elmer/Applied Biosystems). Based on the multiple alignments with the rDNA sequences of the members of the family Desulfurococcaceae, the insertion sites of intron-like sequences were roughly assumed, and then the secondary structures around exon-intron junction sites were manually constructed according to the convention proposed by Thompson \& 
Table 1. Comparison of properties between Aeropyrum camini strain $\mathrm{SY} 1^{\top}$ and $A$. pernix strain $\mathrm{K} 1^{\top}$

Data were taken from this study and Sako et al. (1996a).

\begin{tabular}{|lcc|}
\hline Property & A. camini strain $\mathbf{S Y} \mathbf{1}^{\mathbf{T}}$ & A. pernix strain $\mathbf{~ K 1 ^ { \mathbf { T } }}$ \\
\hline Origin & $\begin{array}{c}\text { Deep-sea hydrothermal } \\
\text { vent chimney }\end{array}$ & $\begin{array}{c}\text { Coastal solfataric } \\
\text { thermal vent }\end{array}$ \\
Cell diameter $(\mu \mathrm{m})$ & $1 \cdot 2-2 \cdot 1$ & $0 \cdot 8-1 \cdot 0$ \\
Inhibition of growth by $\mathrm{S}^{0}$ & + & - \\
Temperature range $\left({ }^{\circ} \mathrm{C}\right)$ & $70-97$ & $70-100$ \\
Temperature optimum $\left({ }^{\circ} \mathrm{C}\right)$ & 85 & $90-95$ \\
pH range & $6 \cdot 5-8 \cdot 8$ & $5 \cdot 0-9 \cdot 0$ \\
pH optimum & $8 \cdot 0$ & $7 \cdot 0$ \\
Salinity range $(\%, \mathrm{w} / \mathrm{v})$ & $2 \cdot 2-5 \cdot 3$ & $1 \cdot 8-7 \cdot 0$ \\
Salinity optimum $(\%, \mathrm{w} / \mathrm{v})$ & $3 \cdot 5$ & $3 \cdot 5$ \\
Genomic DNA $\mathrm{G}+\mathrm{C}$ content $(\mathrm{mol} \%)$ & $54 \cdot 4$ & $56 \cdot 3^{\star}$ \\
\hline
\end{tabular}

${ }^{\star}$ From genome sequence.

Daniels (1988) and Lykke-Andersen et al. (1997). As a result, two putative introns were found in the rDNA sequence. Both of them had a secondary structure specific to archaeal rRNA introns, containing the bulge-helix-bulge core structure; 3-base loops on opposite strands separated by a 4 bp helix.

In order to determine the phylogenetic position of the isolate, the sequence of the putative exon for 16S rRNA gene was manually aligned with a subset of $16 \mathrm{~S}$ rDNA sequences obtained from DDBJ and the Ribosomal Database Project II (RDP-II) (Maidak et al., 2001) by using CLUSTAL X (Thompson et al., 1997). Phylogenetic analyses were restricted to nucleotide positions that were unambiguously alignable in all sequences (Takai \& Horikoshi, 1999a, Takai \& Sako, 1999). Neighbour-joining analysis (Saitou \& Nei, 1987) of 938 bases of sequence from each organism was accomplished using CLUSTAL X. Bootstrap analysis was used for 1000 trial replications to provide confidence estimates for the phylogenetic tree topologies. The phylogenetic tree demonstrated that the new isolate was a close relative of A. pernix strain $\mathrm{K}^{\mathrm{T}}$ (Fig. 2). The similarity of the putative exon sequence for $16 \mathrm{~S}$ rDNA between the isolate and
A. pernix strain $\mathrm{K}^{\mathrm{T}}$ was $99 \cdot 0 \%$. These results indicated that the isolate was a member of the genus Aeropyrum.

DNA-DNA hybridization analysis between the isolate and A. pernix strain $\mathrm{K}^{\mathrm{T}}$ was performed at $37 \cdot 4{ }^{\circ} \mathrm{C}$ for $3 \mathrm{~h}$ and was measured fluorometrically using photobiotin, according to the method of Ezaki et al. (1989). Although the phylogenetic analysis based on the $16 \mathrm{~S}$ rRNA gene sequence indicated that the new isolate was closely related to $A$. pernix strain $\mathrm{K} 1^{\mathrm{T}}$, the mean hybridization value for the isolate and A. pernix strain $\mathrm{K}^{\mathrm{T}}$ was only $5 \cdot 1 \%$. This result indicated that the new isolate could be genotypically differentiated from A. pernix strain $\mathrm{K}^{\mathrm{T}}$.

\section{Comparison with $A$. pernix strain $\mathrm{K}^{\mathrm{T}}$}

The phylogenetic analysis based on the $16 \mathrm{~S}$ rDNA sequence indicated that strain $S Y 1^{\mathrm{T}}$ is closely related to $A$. pernix strain $\mathrm{K}^{\mathrm{T}}$. Analyses of $\mathrm{G}+\mathrm{C}$ content, metabolism, morphological properties, antibiotic susceptibility and nutrition of strain $S Y 1^{\mathrm{T}}$ also support the strain being a member of the genus Aeropyrum, except that the cell diameter of the isolate was larger than that of $A$. pernix

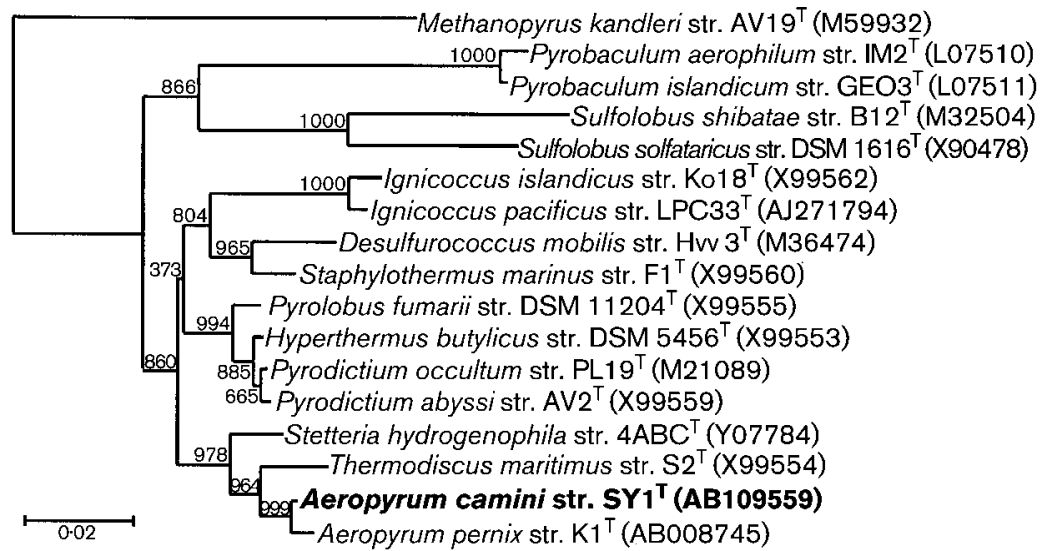

Fig. 2. Phylogenetic tree of representative members of hyperthermophilic archaea, inferred from 16S rDNA sequences (accession numbers in parentheses) by the neighbourjoining method using 938 homologous sequence positions for each organism. The numbers are the bootstrap values for the branches (based on 1000 replicates). Bar, 2 substitutions per 100 nucleotides. 
strain $\mathrm{K}^{\mathrm{T}}$ (Table. 1). As is often observed in 16S rRNA genes of some strains of $A$. pernix (Nomura et al., 2002), strain $S Y 1^{\mathrm{T}}$ possessed two potential short introns with no apparent ORF inside, which were inserted in the identical positions to the rRNA introns $\mathrm{I} \delta$ and $\mathrm{I} \varepsilon$ of strain TB1 (Nomura et al., 2002). The introns in the 16S rDNA of strain $S Y 1^{\mathrm{T}}$, however, were different from those of $A$. pernix strains TB1-8 in length and sequence; 63 bp for the position of I $\delta$ ( $62 \mathrm{bp}$ in strain TB1) and $141 \mathrm{bp}$ for the position of $\mathrm{I} \varepsilon$ (122 bp in strain TB1), and the sequence similarities ( 91.9 and $71.4 \%$ in $I \delta$ and $I \varepsilon$, respectively). The genetic diversity of the rRNA introns may be an important taxonomic feature within the rRNA intron-containing hyperthermophilic archaeal genus Aeropyrum.

The optimum temperature for the growth of strain $S Y 1^{\mathrm{T}}$ was $5-10{ }^{\circ} \mathrm{C}$ lower than that of $A$. pernix strain $\mathrm{K}^{\mathrm{T}}$. The optimum $\mathrm{pH}$ for the growth of strain $S Y 1^{\mathrm{T}}$ was higher than that of $A$. pernix strain $\mathrm{K}^{\mathrm{T}}$, and it is the highest among those of the members of the phylum Crenarchaeota. The $\mathrm{pH}$ and salinity ranges for growth of strain $\mathrm{SY}^{\mathrm{T}}$ was narrower than those of $A$. pernix strain $\mathrm{K}^{\mathrm{T}}$ (Table 1). The effect of thiosulfate on the growth of strain $\mathrm{SY}^{\mathrm{T}}$ was relatively weak; the maximum cell density of strain $S \mathrm{SY}^{\mathrm{T}}$ was increased about twofold by thiosulfate, in contrast to eightfold stimulation of cell density observed in A. pernix strain $\mathrm{K}^{\mathrm{T}}$ (Sako et al., 1996a). In addition, the growth of strain $\mathrm{SY}^{\mathrm{T}}$ was completely inhibited by $\mathrm{S}^{0}$, although A. pernix $\mathrm{K}_{1}^{\mathrm{T}}$ was not affected (Sako et al., 1996a). These physiological properties strongly suggest that strain $S Y 1^{\mathrm{T}}$ can be classified as a different species from the type strain of the genus Aeropyrum, A. pernix strain $\mathrm{K}^{\mathrm{T}}{ }^{\mathrm{T}}$. Finally, DNA-DNA hybridization analysis clearly indicated that the new isolate could be genotypically differentiated from A. pernix strain $\mathrm{K}^{\mathrm{T}}$. On the basis of these physiological and genetic properties, we propose a new species, Aeropyrum camini; the type strain is strain $\mathrm{SY}^{\mathrm{T}}(=\mathrm{JCM}$ $12091^{\mathrm{T}}=$ ATCC BAA $-758^{\mathrm{T}}$ ).

Strain $S Y 1^{\mathrm{T}}$ is the first strictly aerobic hyperthermophilic micro-organism isolated from a deep-sea hydrothermal environment, although a number of strictly anaerobic and heterotrophic hyperthermophiles such as the members of Thermococcales (e.g. Erauso et al., 1993; González et al., 1995, 1998; Godfroy et al., 1997; Canganella et al., 1998; Takai et al., 2000), Archaeoglobales (Burggraf et al., 1990; Kashefi et al., 2002) and Desulfurococcales (Fiala et al., 1986; Pley et al., 1991) have been isolated. Successful cultivation of A. camini strain $S Y 1^{\mathrm{T}}$ only from the surface zone of the chimney structure provides an important clue into delineation of the ecological niche of the strictly aerobic hyperthermophiles at deep-sea hydrothermal systems. In very steep physical and geochemical gradients formed in the chimney structure, the highly reductive and the relatively oxidative microhabitats concomitantly occur by means of mixing between anoxic hot fluid and oxygenated sea water. We also succeeded in isolating strictly aerobic thermophiles, Marinithermus hydrothermalis strain $\mathrm{T}^{\mathrm{T}}$ and Rhodothermus sp. (Sako et al., 2003), and also the facultatively anaerobic thermophile Persephonella hydrogeniphila strain $29 \mathrm{~W}^{\mathrm{T}}$ (Nakagawa et al., 2003) and the strictly anaerobic thermophile Deferribacter desulfuricans strain $\mathrm{SSM1}^{\mathrm{T}}$ (Takai et al., 2003a) from the same subsample used in this study. These new thermophiles from a surface layer of the chimney represent a glimpse into the potentially vast microbial diversity at the thin interface zone between hot fluid and cold sea water. The ecological potential of decomposition of organic materials by strictly aerobic, hyperthermophilic heterotrophs in the deep-sea hydrothermal vent environments is the focus of our future investigation.

\section{Description of Aeropyrum camini sp. nov.}

Aeropyrum camini (ca'mi.ni. L. gen. n. camini of a chimney, relating to its isolation from a hydrothermal vent chimney).

Cells are motile and irregular cocci, about $1 \cdot 2-2 \cdot 1 \mu \mathrm{m}$ in diameter. Gram-negative. Growth occurs at $70-97^{\circ} \mathrm{C}$ (optimum, $85^{\circ} \mathrm{C}$ ), at $\mathrm{pH} 6 \cdot 5-8 \cdot 8$ (optimum, $8 \cdot 0$ ) and at $2 \cdot 2-5 \cdot 3 \%$ salinity (optimum, $3 \cdot 5 \%$ ). Optimal doubling time is about $4 \mathrm{~h}$. Strictly aerobic heterotroph. Growth is completely inhibited by $S^{0}$. Utilizes only complex proteinaceous compounds, such as yeast extract and tryptone as sole energy and carbon sources. $\mathrm{G}+\mathrm{C}$ content is $54 \cdot 4 \mathrm{~mol} \%$ (HPLC). DNA-DNA relatedness to A. pernix $\mathrm{K} 1^{\mathrm{T}}$ is low.

The type strain is SY1 ${ }^{\mathrm{T}}\left(=\mathrm{JCM} 12091^{\mathrm{T}}=\right.$ ATCC BAA- $\left.-758^{\mathrm{T}}\right)$, which was isolated from a deep-sea hydrothermal vent chimney at Suiyo Seamount in the Izu-Bonin Arc, Japan $\left(28^{\circ} 34 \cdot 287^{\prime} \mathrm{N}, 140^{\circ} 38 \cdot 663^{\prime} \mathrm{E}\right.$; depth $\left.1385 \mathrm{~m}\right)$.

\section{Acknowledgements}

We would like to thank the captain and crew of R/V Natsushima and Shinkai 2000 for helping us to obtain deep-sea hydrothermal vent samples. We are grateful to Mr Takahiko Higasa, Graduate School of Agriculture, Kyoto University, Japan, for the electron micrographs. This work was partially supported by a Grant-in-Aid for Science Research (no. 12460093) from the Ministry of Education, Culture, Sports, Science and Technology of Japan. S. N. was supported by a Research Fellowship of the JSPS.

\section{References}

Amo, T., Paje, M. L. F., Inagaki, A., Ezaki, S., Atomi, H. \& Imanaka, T. (2002). Pyrobaculum calidifontis sp. nov., a novel hyperthermophilic archaeon that grows under atmospheric air. Archaea 1, 113-121.

Balch, W. E., Fox, G. E., Magrum, L. J., Woese, C. R. \& Wolfe, R. S. (1979). Methanogens: reevaluation of a unique biological group. Microbiol Rev 43, 260-296.

Blöchl, E., Rachel, R., Burggraf, S., Jannasch, H. W. \& Stetter, K. O. (1997). Pyrolobus fumarii, gen. and sp. nov., represents a novel group of archaea, extending the upper temperature limit of life to $113^{\circ} \mathrm{C}$. Extremophiles 1, 14-21.

Burggraf, S., Jannasch, H. W., Nicolaus, B. \& Stetter, K. O. (1990). Archaeoglobus profundus, sp. nov., represents a new species within the sulfate-reducing archaebacteria. Syst Appl Microbiol 13, 24-28. 
Burggraf, S., Larsen, N., Woese, C. R. \& Stetter, K. O. (1993). An intron within the $16 \mathrm{~S}$ ribosomal RNA gene of the archaeon Pyrobaculum aerophilum. Proc Natl Acad Sci U S A 90, 2547-2550.

Canganella, F., Jones, W. J., Gambacorta, A. \& Antranikian, G. (1998). Thermococcus guaymasensis sp. nov. and Thermococcus aggregans sp. nov., two novel thermophilic archaea isolated from the Guaymas Basin hydrothermal vent site. Int J Syst Bacteriol 48, 1181-1185.

Daimon, K., Kawarabayasi, Y., Kikuchi, H., Sako, Y. \& Ishino, Y. (2002). Three proliferating cell nuclear antigen-like proteins found in the hyperthermophilic archaeon Aeropyrum pernix: interactions with the two DNA polymerases. J Bacteriol 184, 687-694.

DeLong, E. F. (1992). Archaea in coastal marine environments. Proc Natl Acad Sci U S A 89, 5685-5689.

Erauso, G., Reysenbach, A.-L., Godfroy, A. \& 8 other authors (1993). Pyrococcus abyssi sp. nov., a new hyperthermophilic archaeon isolated from a deep-sea hydrothermal vent. Arch Microbiol 160, 338-349.

Ezaki, T., Hashimoto, Y. \& Yabuuchi, E. (1989). Fluorometric deoxyribonucleic acid-deoxyribonucleic acid hybridization in microdilution wells as an alternative to membrane filter hybridization in which radioisotopes are used to determine genetic relatedness among bacterial strains. Int J Syst Bacteriol 39, 224-229.

Fiala, G., Stetter, K. O., Jannasch, H. W., Langworthy, T. A. \& Madon, J. (1986). Staphylothermus marinus sp. nov. represents a novel genus of extremely thermophilic submarine heterotrophic archaebacteria growing up to $98^{\circ} \mathrm{C}$. Syst Appl Microbiol 8, 106-113.

Godfroy, A., Lesongeur, F., Raguenes, G., Querellou, J., Antoine, E., Meunier, J. R., Guezennec, J. \& Barbier, G. (1997). Thermococcus hydrothermalis sp. nov., a new hyperthermophilic archaeon isolated from a deep-sea hydrothermal vent. Int J Syst Bacteriol 47, 622-626.

González, J. M., Kato, C. \& Horikoshi, K. (1995). Thermococcus peptonophilus sp. nov., a fast-growing, extremely thermophilic archaebacterium isolated from deep-sea hydrothermal vents. Arch Microbiol 164, 159-164.

González, J. M., Masuchi, Y., Robb, F. T., Ammerman, J. W., Maeder, D. L., Yanagibayashi, M., Tamaoka, J. \& Kato, C. (1998). Pyrococcus horikoshii sp. nov., a hyperthermophilic archaeon isolated from a hydrothermal vent at the Okinawa Trough. Extremophiles 2, 123-130.

Grogan, D., Palm, P. \& Zillig, W. (1990). Isolate B12, which harbours a virus-like element, represents a new species of the archaebacterial genus Sulfolobus, Sulfolobus shibatae, sp. nov. Arch Microbiol 154, 594-599.

Hansen, T., Reichstein, B., Schmid, R. \& Schonheit, P. (2002). The first archaeal ATP-dependent glucokinase, from the hyperthermophilic crenarchaeon Aeropyrum pernix, represents a monomeric, extremely thermophilic ROK glucokinase with broad hexose specificity. J Bacteriol 184, 5955-5965.

Huber, H. \& Stetter, K. O. (2001). Family I. Desulfurococcaceae. In Bergey's Manual of Systematic Bacteriology, 2nd edn, vol. 1 (The Archaea and the Deeply Branching and Phototrophic Bacteria), pp. 180-181. Edited by D. R. Boone, R. W. Castenholz \& G. M. Garrity. New York: Springer.

Itoh, T., Suzuki, K. \& Nakase, T. (1998). Occurrence of introns in the $16 \mathrm{~S}$ rRNA genes of members of the genus Thermoproteus. Arch Microbiol 170, 155-161.

Jan, R. L., Wu, J., Chaw, S. M., Tsai, C. W. \& Tsen, S. D. (1999). A novel species of thermoacidophilic archaeon, Sulfolobus yangmingensis sp. nov. Int J Syst Bacteriol 49, 1809-1816.

Jeon, S. J. \& Ishikawa, K. (2002). Identification and characterization on thioredoxin and thioredoxin reductase from Aeropyrum pernix K1. Eur J Biochem 269, 5423-5430.
Kashefi, K., Tor, J. M., Holmes, D. E., Gaw Van Praagh, C. V., Reysenbach, A.-L. \& Lovley, D. R. (2002). Geoglobus ahangari gen. nov., sp. nov., a novel hyperthermophilic archaeon capable of oxidizing organic acids and growing autotrophically on hydrogen with $\mathrm{Fe}(\mathrm{III})$ serving as the sole electron accepter. Int J Syst Evol Microbiol 52, 719-728.

Kawarabayasi, Y., Hino, Y., Horikawa, H. \& 22 other authors (1999). Complete genome sequence of an aerobic hyperthermophilic crenarchaeon, Aeropyrum pernix K1. DNA Res 6, 83-101; 145-152.

Kurosawa, N., Itoh, Y. H., Iwai, T., Sugai, A., Uda, I., Kimura, N., Horiuchi, T. \& Itoh, T. (1998). Sulfurisphaera ohwakuensis gen. nov., sp. nov., a novel extremely thermophilic acidophile of the order Sulfolobales. Int J Syst Bacteriol 48, 451-456.

Lane, D. J. (1985). 16S/23S rRNA sequencing. In Nucleic Acid Techniques in Bacterial Systematics, pp. 115-175. Edited by E. Stackebrandt \& M. Goodfellow. Chichester: Wiley.

Lauerer, G., Kristjánsson, J. K., Langworthy, T. A., König, H. \& Stetter, K. O. (1986). Methanothermus sociabilis sp. nov., a second species within the Methanothermaceae growing at $97^{\circ} \mathrm{C}$. Syst Appl Microbiol 8, 100-105.

Lykke-Andersen, J., Aagaard, C., Seminenkov, M. \& Garrett, G. A. (1997). Archaeal introns: splicing, intercellular mobility and evolution. Trends Biochem Sci 22, 326-331.

Maidak, B. L., Cole, J. R., Lilburn, T. G. \& 7 other authors (2001) The RDP-II (Ribosomal Database Project). Nucleic Acids Res 29, 173-174.

Marteinsson, V. T., Birrien, J. L., Kristjánsson, J. K. \& Prieur, D. (1995). First isolation of thermophilic aerobic nonsporulating heterotrophic bacteria from deep-sea hydrothermal vents. FEMS Microbiol Ecol 18, 163-174.

Marteinsson, V. T., Birrien, J. L., Raguénès, G., da Costa, M. S. \& Prieur, D. (1999). Isolation and characterization of Thermus thermophilus Gy1211 from a deep-sea hydrothermal vent. Extremophiles 3, 247-251.

Miroshnichenko, M. L., L'Haridon, S., Jeanthon, C. \& 7 other authors (2003a). Oceanithermus profundus gen. nov., sp. nov., a thermophilic, microaerophilic facultatively chemolithoheterotrophic bacterium from a deep-sea hydrothermal vent. Int J Syst Evol Microbiol 53, 747-752.

Miroshnichenko, M. L., L'Haridon, S., Nercessian, O. \& 8 other authors (2003b). Vulcanithermus mediatlanticus gen. nov., sp. nov., a novel member of the family Thermaceae from a deep-sea hot vent. Int J Syst Evol Microbiol 53, 11443-1148.

Nakagawa, S., Takai, K., Horikoshi, K. \& Sako, Y. (2003). Persephonella hydrogeniphila sp. nov., a novel thermophilic, hydrogenoxidizing bacterium from a deep-sea hydrothermal vent chimney. Int J Syst Evol Microbiol 53, 863-869.

Nomura, N., Sako, Y. \& Uchida, A. (1998). Molecular characterization and postsplicing fate of three introns within the single rRNA operon of the hyperthermophilic archaeon Aeropyrum pernix K1. J Bacteriol 180, 3635-3643.

Nomura, N., Morinaga, Y., Kogishi, T., Kim, E. J., Sako, Y. \& Uchida, A. (2002). Heterogeneous yet similar introns reside in identical positions of the rRNA genes in natural isolates of the archaeon Aeropyrum pernix. Gene 295, 43-50.

Pley, U., Schipka, J., Gambacorta, A., Jannasch, H. W., Fricke, H., Rachel, R. \& Stetter, K. O. (1991). Pyrodictium abyssi, sp. nov., represents a novel heterotrophic marine archaeal hyperthermophile growing at $110^{\circ}$ C. Syst Appl Microbiol 14, 245-253.

Porter, K. G. \& Feig, Y. S. (1980). The use of DAPI for identifying and counting microflora. Limnol Oceanogr 25, 943-948. 
Saitou, N. \& Nei, M. (1987). The neighbor-joining method: a new method for reconstructing phylogenetic trees. Mol Biol Evol 4, 406-425.

Sako, Y., Nomura, N., Uchida, A., Ishida, Y., Morii, H., Koga, Y., Hoaki, T. \& Maruyama, A. (1996a). Aeropyrum pernix gen. nov., sp. nov., a novel aerobic hyperthermophilic archaeon growing at temperatures up to $100^{\circ} \mathrm{C}$. Int J Syst Bacteriol 46, 1070-1077.

Sako, Y., Takai, K., Ishida, Y., Uchida, A. \& Katayama, Y. (1996b). Rhodothermus obamensis sp. nov., a modern lineage of extremely thermophilic marine bacteria. Int J Syst Bacteriol 46, 1099-1104.

Sako, Y., Croocker, P. C. \& Ishida, Y. (1997). An extremely heatstable extracellular proteinase (aeropyrolysin) from the hyperthermophilic archaeon Aeropyrum pernix K1. FEBS Lett 415, 329-334.

Sako, Y., Nunoura, T. \& Uchida, A. (2001). Pyrobaculum oguniense sp. nov., a novel facultatively aerobic and hyperthermophilic archaeon growing at up to $97^{\circ} \mathrm{C}$. Int J Syst Evol Microbiol 51, 303-309.

Sako, Y., Nakagawa, S., Takai, K. \& Horikoshi, K. (2003). Marinithermus hydrothermalis gen. nov., sp. nov., a strictly aerobic, thermophilic bacterium from a deep-sea hydrothermal vent chimney. Int J Syst Evol Microbiol 53, 59-65.

Segerer, A., Neuner, A. M., Kristjansson, J. K. \& Stetter, K. O. (1986). Acidianus infernus gen. nov., sp. nov., and Acidianus brierleyi comb. nov. facultatively aerobic, extremely acidophilic thermophilic sulfur-metabolizing archaebacteria. Int J Syst Bacteriol 36, 559-564.

Suzuki, T., Iwasaki, T., Uzawa, T., Hara, K., Nemoto, N., Kon, T., Ueki, T., Yamagishi, A. \& Oshima, T. (2002). Sulfolobus tokodaii sp. nov. (f. Sulfolobus sp. strain 7), a new member of the genus Sulfolobus isolated from Beppu Hot Springs, Japan. Extremophiles 6, 39-44.

Tachibana, A., Yano, Y., Otani, S., Nomura, N., Sako, Y. \& Taniguchi, M. (2000). Novel prenyltransferase gene encoding farnesylgeranyl diphosphate syntheses from a hyperthermophilic archaeon, Aeropyrum pernix. Molecular evolution with alteration in product specificity. Eur J Biochem 267, 321-328.

Takai, K. \& Horikoshi, K. (1999a). Genetic diversity of archaea in deep-sea hydrothermal vent environments. Genetics 152, 1285-1297.

Takai, K. \& Horikoshi, K. (1999b). Molecular phylogenetic analysis of archaeal intron-containing genes coding for rRNA obtained from a deep-subsurface geothermal water pool. Appl Environ Microbiol 65, $5586-5589$.
Takai, K. \& Sako, Y. (1999). A molecular view of archaeal diveristy in marine and terrestrial hot water environments. FEMS Microbiol Ecol 28, 177-188.

Takai, K., Sugai, A., Itoh, T. \& Horikoshi, K. (2000). Palaeococcus ferrophilus gen. nov., sp. nov., a barophilic, hyperthermophilic archaeon from a deep-sea hydrothermal vent chimney. Int J Syst Evol Microbiol 50, 489-500.

Takai, K., Kobayashi, H., Nealson, K. H. \& Horikoshi, K. (2003a). Deferribacter desulfuricans sp. nov., a novel sulfur-, nitrate- and arsenate-reducing thermophile isolated from a deep-sea hydrothermal vent. Int J Syst Evol Microbiol 53, 823-827.

Takai, K., Inagaki, F., Nakagawa, S., Hirayama, H., Nunoura, T., Sako, Y., Nealson, K. H. \& Horikoshi, K. (2003b). Isolation and phylogenetic diversity of members of previously uncultivated $\varepsilon^{-}$ Proteobacteria in deep-sea hydrothermal fields. FEMS Microbiol Lett 218, 167-174.

Tamaoka, J. \& Komagata, K. (1984). Determination of DNA base composition by reverse-phase high-performance liquid chromatography. FEMS Microbiol Lett 25, 125-128.

Thompson, L. D. \& Daniels, C. J. (1988). A tRNA ${ }^{\mathrm{Tr}}$ intron endonuclease from Halobacterium volcanii: unique substrate recognition properties. J Biol Chem 263, 17951-17959.

Thompson, T. D., Gibosn, T. J., Plewniak, F., Jeanmougin, F. \& Higgins, D. G. (1997). The CLUSTAL X Windows interface: flexible strategies for multiple sequence alignment aided by quality analysis tools. Nucleic Acids Res 25, 4876-4882.

Yamano, S., Sako, Y., Nomura, N. \& Maruyama, T. (1999). A cambialistic SOD in a strictly aerobic hyperthermophilic archaeon, Aeropyrum pernix. J Biochem (Tokyo) 126, 218-225.

Zillig, W., Stetter, K. O., Wunderl, S., Schulz, W., Priess, H. \& Scholz, I. (1980). The Sulfolobus-"Caldariella" group: taxonomy on the basis of the structure of DNA-dependent RNA polymerases. Arch Microbiol 125, 259-269.

Zillig, W., Yeats, S., Holz, I., Bock, A., Rettenberger, M., Gropp, F. \& Simon, G. (1986). Desulfurolobus ambivalens, gen. nov., sp. nov., an autotrophic archaebacterium facultatively oxidizing or reducing sulfur. Syst Appl Microbiol 8, 197-203.

Zillig, W., Holz, I., Janekovic, D. \& 7 other authors (1990). Hyperthermus butylicus, a hyperthermophilic sulfur-reducing archaebacterium that ferments peptides. J Bacteriol 172, 3959-3965. 